\title{
Behavior of Salmonella heidelberg in fruit juices
}

\author{
El-Safey Mohamed El-Safey
}

Faculty of Science, Al-Azhar University. Assuit branch, P.O. 71542, .Assuit. EGYPT

on Secondment to College of Applied Medical Science, Majmaah University, AlMajmaah, 11952, Pox. 1816, KSA

\section{Email address:}

e.mabrouk@mu.edu.sa (El-Safey Mohamed El-Safey), elsafey5@hotmail.com (El-Safey Mohamed El-Safey)

\section{To cite this article:}

El-Safey Mohamed El-Safey. Behavior of Salmonella Heidelberg in Fruit Juices, International Journal of Nutrition and Food Sciences. Vol. 2, No. 2, 2013, pp. 38-44. doi: 10.11648/j.ijnfs.20130202.13

\begin{abstract}
The aim of the study is determination of the behavior of Salmonella heidelberg under acidic conditions and variable temperatures. The growth and survival of Salmonella heidelberg (10 isolates) in fresh fruit juices including; apple ( $\mathrm{pH}, 3.2-1.4)$, orange $(\mathrm{pH}, 5.4-1.5)$, mango $(\mathrm{pH}, 5.4-2.8)$, guava $(\mathrm{pH}, 5.7-2.4)$, pineapple $(\mathrm{pH}, 5.6-2.3)$, and cocktail ( $\mathrm{pH}$, 5.7-2.3) were determined after $0,3,6,9,12,15,18$ and 21 days of storage at $10{ }^{\circ} \mathrm{C}, 0,3,6,9,12$ and 15 days of storage at 25 ${ }^{\circ} \mathrm{C}$, and $0,3,6$ and 9 days of storage at $37^{\circ} \mathrm{C}$. Survival in fruit juices depended upon their $\mathrm{pH}$, the type of strain, the type of juices and the incubation temperature. Salmonella heidelberg Survived for up to $18 \mathrm{~d}$ in mango, guava, pineapple and cocktail juices, orange juice for up to $15 \mathrm{~d}$ and apple juice for up to $12 \mathrm{~d}$ stored at $10^{\circ} \mathrm{C}$. At $20^{\circ} \mathrm{C}$, Salmonella heidelberg was survived for up to $12 \mathrm{~d}$ in guava, pineapple and cocktail juices, $9 \mathrm{~d}$ for mango juice, orange juice for up to $9 \mathrm{~d}$ and apple juice for up to $6 \mathrm{~d}$. The shortest survival time was observed at $37^{\circ} \mathrm{C}$ for $9 \mathrm{~d}$ in mango, guava, pineapple, cocktail juices, $6 \mathrm{~d}$ for orange as well as $3 \mathrm{~d}$ for apple juices respectively. These findings indicated that, as temperatures of acidify fresh fruit juices (apple, orange, mango, guava, pineapple and cocktail juices, respectively) increase as Salmonella heidelberg population decrease. The author reported that, Acid foods, especially if kept at refrigeration temperatures, support survival of Salmonella heidelberg and may cause Salmonella heidelberg food poisoning.
\end{abstract}

Keywords: Salmonella Heidelberg, Behavior, Fruit Juices, pH And Temperature

\section{Introduction}

Salmonella sp. are food-borne pathogens of major public health concern in most countries of the world. Salmonella enterica is an important zoonotic pathogen that causes an estimated 1.4 million illnesses, 16,000 hospitalizations, and between 400 and 600 deaths annually in the United States alone $[1,2]$. Salmonella infections have become one of the most important groups of bacterial diseases affecting poultry, and, according to [3] domestic poultry constitutes the largest single reservoir of salmonella organisms existing in nature.

In the United States and Canada, Salmonella serovar Heidelberg is among the most frequently isolated serovars both in clinical cases of salmonellosis and from retail meats and food animals. Salmonella serovar heidelberg ranked first and fourth among serovars from food animals in 2002 and 2003, respectively [50], and ranked fifth and fourth among serovars from human in 2003 and 2004, respectively $[4,5]$.

Salmonella heidelberg was the most common serovar found in retail meats in both years $[6,7]$ and was found exclusively in poultry meats. The notion that poultry is the major reservoir of human infections in the United States and Canada is supported by case-control studies implicating table eggs [8,9] and chicken meat [9] as being the main sources of Salmonella serovar Heidelberg infections. Salmonella serovar heidelberg is a major serovar only in the United States and Canada and is not among the top six serovars in other continents [10]. Epidemic outbreaks of Salmonella serovar heidelberg present a significant public health and economic burden in the region [11]. Salmonella serovar heidelberg has caused large outbreaks of food-borne illness in nursing homes, in hospitals, and within the community [12-15].

Unpasteurized fresh fruit is a traditional product that is produced and consumed in the regions of the world, particularly during the fall harvest season. However, this product has been implicated as the vechle for food-borne diseases. Salmonella species are responsible for the highest number of documents cases of food poisoning in the developed country $[16,17]$. A variety of foods, including poultry, eggs, meat, milk, fruits, and vegetables, have been implicated as vehicles of one or more of these pathogens in outbreaks of 
food-borne illness [18-20]. Salmonella is an enterinvasive bacterium and causes infections that may have one of five different clinical presentations [21, 22]. Gastroenteritis is the most common presentation in industrial countries and is considering as an emergent food-borne pathogen caused disease it's a self-limited illness of brief duration, usually characterized by diarrhea and fever [23]. Salmonella heidelberg is an important human pathogen, which causes diarrhea diseases.

Many of the studies describing the survival of infectious pathogens in foods carried out in recent years have focused on or included Salmonella heidelberg as a target organism. Many of the studies have been done to determine the effect of environmental conditions on the survival and growth of pathogenic bacteria. There are a number of considerations to make when carrying out survival studies. Strain to strain variability has been shown to be important for some conditions. The $\mathrm{pH}$-dependent and $\mathrm{pH}$-independent stationary-phase acid tolerant phenotypes. In addition to that the preadaptation of cells is important for survival studies with acid foods [24].

The recovery method and medium may underestimate the numbers of survivors present if those organisms are stressed. If selective media are used to recover injured or stressed cells, modification to the recovery protocol may be required as described by [25]. In addition to the recovery medium, the composition of diluent used for serial dilutions may be also important [26]. Other factors shown to be important for survival include $\mathrm{pH}$ and acid type [27] and storage temperature or for inadequately short incubation periods [28]. The present work aimed at providing data on behaviour of Salmonella heidelberg in fruit juices during storage for variable time and temperature.

\section{Materials and Methods}

\subsection{Inoculum Preparation}

Three strains of Salmonella heidelberg were studied. Cultures were maintained on tryptic soya agar (TSA; 7.0; Difco, Laboratories, Detroit, MI) slants at $5{ }^{\circ} \mathrm{C}$ with monthly transfers to maintain viable cells and propagated in tryptic soy broth (TSB, Difco) for $24 \mathrm{~h}$ at $37{ }^{\circ} \mathrm{C}$ to provide approximately $106 \mathrm{CFU} / \mathrm{ml}-1$. Cultures of the three isolates were combined in equal volumes to serve as a mixture to be used as inocula for the experiments.

\subsection{Fruit Juices}

Commercial, pasteurized clarified six different fruit juices including, apple, orange, mango, guava, pineapple, and cocktail, were purchased from the local supermarkets. No preservatives and artificial color was added (i.e. did not contain any of microbial inhibitors).

\subsection{Inoculation of Fruit Juices}

For inoculating fruit juices samples populations of Salmonella heidelberg were applied as mentioned by [29]. A population suspension (106 CFU ml-1) of Salmonella heidelberg was prepared by adding $10 \mathrm{ml}-1$ of the undiluted 3 -isolates mixture to 10 liters of $0.1 \%$ peptone water. On the other hand, each fruit juices sample included control, which was un-inoculated. The population suspensions were prepared to obtain a final concentration on the fruit juices samples (106 CFU/ml-1).

\subsection{Storage Conditions}

Fruit juices samples $(2000 \mathrm{ml})$ of each juice were placed into separate sterilized conical flasks. Fruit juices samples were stored for time intervals of $0,3,6,9,12,15,18$ and 21 days at $10^{\circ} \mathrm{C}$. Subsequently, $0,3,6,9,12$ and 15 days at $20^{\circ} \mathrm{C}$ as well as $0,3,6$ and 9 days at $37^{\circ} \mathrm{C}$. before microbiological analyses respectively. For microbiological analysis samples were taken after 3 days.

\section{5. pH Measurement}

The $\mathrm{pH}$ of fruit juices samples were measured after time intervals of 10 to $20 \mathrm{~min}$ at each time of microbiological analysis using a model Jenway $3020 \mathrm{pH}$ meter.

\subsection{Microbiological Analyses}

At each sampling time, duplicates of $50 \mathrm{ml}$ fruit juices from each sample were analyzed. Samples were combined with $225 \mathrm{ml}$ sterile $0.1 \%$ peptone water (Difco; pH 7.0) in sterilized conical flasks and mixed. The resulting fruit juices slurries were serially diluted in $0.1 \%$ peptone water. Aliquots of $0.1 \mathrm{ml}$ were plated in duplicates onto nutrient agar (Oxoid) and modified brilliant green agar (MBGA) (Oxoid) and xylose-lysine-desoxycholate agar (XLDA) (Oxoid) to facilitate detection of Salmonella heidelberg populations inoculated onto fruit juices and for differentiating test isolates used from other organisms which might present in fruit juices samples. Plates were incubated at $37^{\circ} \mathrm{C}$ for 18 to $24 \mathrm{~h}$ before Salmonella heidelberg colonies were counted. Samples yielding colonies eventually confirmed by biochemical and serological tests to Salmonella heidelberg were recorded positive.

To evaluate the absence of viable Salmonella heidelberg populations in the negative samples, aliquots of $25 \mathrm{ml}$ of the enrichments were combined with $225 \mathrm{ml}$ of modified brilliant green agar (MBGA) (Oxoid) and xylose- lysine- desoxycholate agar (XLDA) (Oxoid. Enriched cultures $(100 \mu \mathrm{l})$ were plated on MBGA and XLDA and incubated for 18 to 20 h at $37^{\circ} \mathrm{C}$.

\subsection{Statistical Analyses}

Data were subjected to the statistical analysis system (SAS Institute, Cary, N.C.) for analysis of variance and Duncan's multiple range testes. Each value presented the mean of eight values (duplicate values from duplicate samples analyzed from two independent trials).

\section{Results and Discussion}


Fruit juices are an important part of the modern diet in many countries. The bacteriological survey of commercially sold, pasteurized, shelf-stable fruit juices from retail markets. The $\mathrm{pH}$ of the tested juices was 2.4-4.8. Bacteria were isolated from 51 samples (42.5\%) and fungi from 78 samples (65\%). Escherichia coli O157:H7 was detected in four of the analyzed samples (3.34\%), and Staphylococcus aureus was detected in four different samples (3.34\%). In 11 samples $(9.1 \%)$, the total number of microorganisms detected was as high as 125 colony forming units (CFU). Acidophilic microorganisms were isolated from 26 samples $(21.7 \%)$ and Blastomyces was detected in 46 samples (38.3\%). Many of the microorganisms detected may cause disease in humans; thus, a number of the tested samples did not meet the Greek guidelines for the microbiological quality of juices. Use of a Hazard Analysis Critical Control Point (HACCP) system should be generally introduced into the juice industry sector to improve the quality of fruit juices, as well as other manufactured foods [30].

The Food and Drug Administration (FDA) has recently concluded that there is a risk of serious illness from consuming juice products that have not been processed in a manner designed to destroy target pathogens, including E. coli O157:H7 and Salmonella spp. Thus, in 1998 the FDA published regulations requiring a warning statement on packaged juices not processed in a manner to produce at least a 5- $\log 10$ - unit reduction in the pertinent target microorganism for a period of at least as long as the shelf life of the product when stored under normal and moderate abuse conditions [31].

In addition to that, In total, 33 cases were reported, and a matched case-control study ( 23 cases/ 24 controls) identified consumption of fresh (unpasteurized) fruit juice purchased from a large retailer $(\mathrm{X})$ as the only significant risk factor for illness (matched odds ratio: 7.4, 95\% confidence interval: 1.5-37.2). Though the bacterium could not be isolated from fruit juice, the minimal $\mathrm{pH}$ value for growth of the causative strain of the outbreak (3.4) was compatible with survival in fruit juice from $X$. The outbreak strain showed acid resistance and adaptive properties that may explain how it could have caused infection through fresh orange juice [32]. To our knowledge, this is the first study related to survival and growth of Salmonella heidelberg in fruit juices. Survival of Salmonella heidelberg during storage in different fresh fruit juices including; apple, orange, mango, guava, pineapple, and cocktail at 10,20 and $37^{\circ} \mathrm{C}$, were observed.

A limited number of studies have evaluated the ability of Salmonella hiedelberg to survive and grow in acidifies fruit juices. Survival in fruit juices depended upon their $\mathrm{pH}$, the type of strain, the type of juice and the incubation temperature [33].

At $10{ }^{\circ} \mathrm{C}$, the results of the present study indicated that, Salmonella hiedelberg were survived on fresh fruit juices throughout 21 days of storage (Fig. 1), death was more rapid as the acidity of juices increased and reached to zero level (undetectable) of Salmonella hiedelberg population. Salmonella hiedelberg survived up to 18 days in mango $(\mathrm{pH}$,
4.8-3), guava ( $\mathrm{pH}, 5.21-3.14)$, pineapple $(\mathrm{pH}, 5.22-3.16)$, and cocktail $(\mathrm{pH}, 5-3)$ juices, while, in orange $(\mathrm{pH}, 3.23$ $-2.03)$ juice survived for up to 15 days and apple $(\mathrm{pH}$, 3.08-1.58) juice for up to 12 days (Fig. 1). Control samples, untreated with Salmonella hiedelberg were observed.

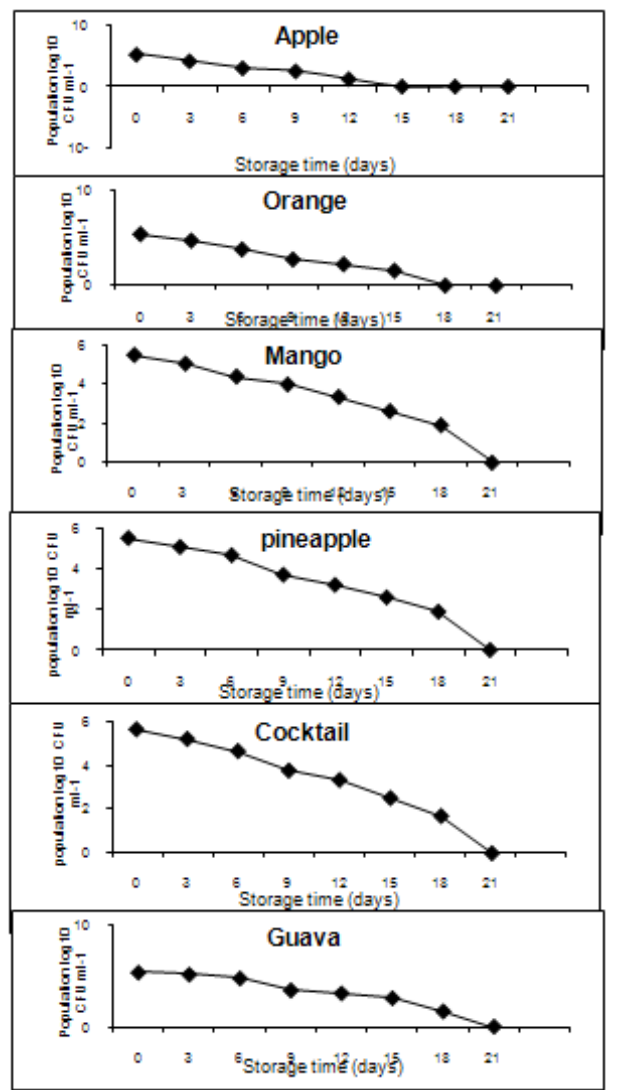

Fig.. 1. Showing changes in population of Salmonella heidelberg in fruit juices during storage at $10^{\circ} \mathrm{C}$ for up to 21 days.

Significant changes in $\mathrm{pH}$ values of fresh fruit juices were observed during storage treated with Salmonella hiedelberg (Fig. 4, A). The same results were reported by El-Safey [34] showing that, the use of higher acids concentration should result in a higher reduction of the bacterial load at all. Similarly, bacterial reduction was optimal at higher concentrations of acids, combination of acids, if the acid temperature was elevated, or if bacteria were attached to adipose tissue [35-37]. In addition to that, bacterial reductions were maximal with higher concentrations of acids [35-37]. 


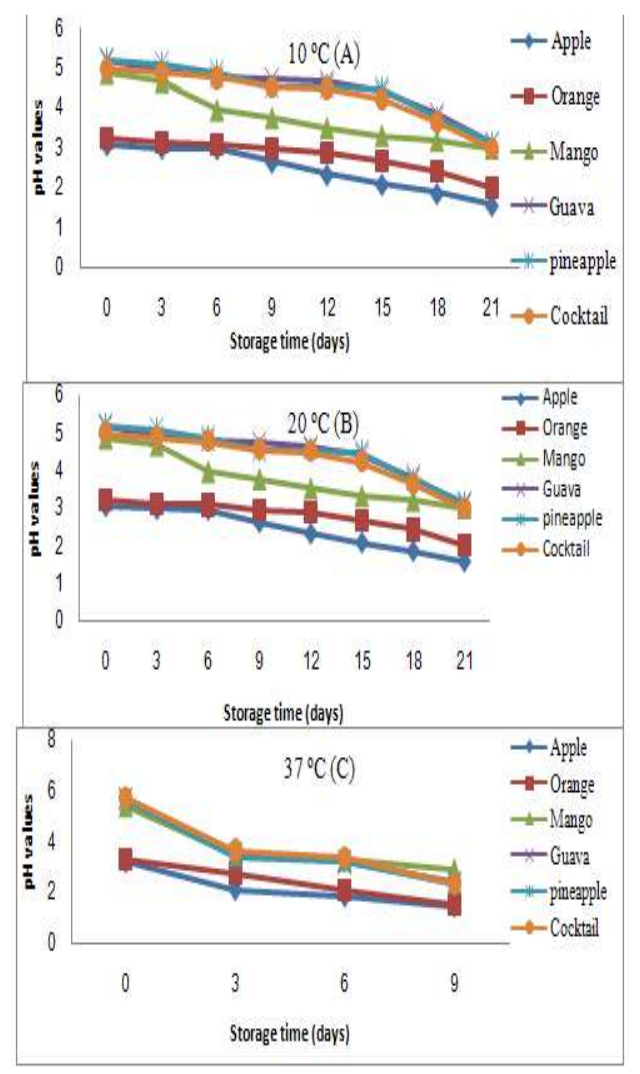

Fig. 4. Showing the changes in $\mathrm{pH}$ values of fruit juices inoculated with Salmonella heidelberg stored at $10{ }^{\circ} \mathrm{C}$ for up to 21 days (A), $20{ }^{\circ} \mathrm{C}$ for up to 18 days $(B)$ and $37^{\circ} \mathrm{C}$ for up to 9 days $(C)$, respectively.

On the other hand, several foodborne human pathogens, when exposed to harsh conditions, enter viable but nonculturable (VBNC) state; however, still open is the question whether VBNC pathogens could be a risk for public health, because, potentially, they can resuscitate. Moreover, cultural methods for food safety control were not able to detect VBNC forms of foodborne bacteria. Particularly, it has not been established whether food chemophysical characteristics can induce VBNC state in contaminating pathogen bacterial populations, especially in food, such as salads and fresh fruit juices, not subjected to any decontamination treatment. Salmonella Typhimurium and S. flexneri, depending on inoculum size, lost culturability but maintained viability and were able to resuscitate; moreover, S. flexneri was still able to form colonies after $48 \mathrm{~h}$ at high inoculum size. However, the entry into VBNC state differs on the species, depending, in turn, on inoculum size and time of incubation [38].

At $20{ }^{\circ} \mathrm{C}$, Salmonella heidelberg succeeded to survive for up to 12 days in guava, pineapple and cocktail juices. In mango and orange juice the pathogen survived for up to 9 days. Moreover, Salmonella hiedelberg in apple juices survived for up to 6 days (Fig. 2). The significant decrease in Salmonella hiedelberg populations occurred in apple, orange, mango, guava, pineapple and cocktail it might refer to the acidity of juices. Significant changes in $\mathrm{pH}$ values of fruit juices may contribute to the major effect on Salmonella heidelberg during storage at $20{ }^{\circ} \mathrm{C}$ (Fig. 4, B). Growth oc- curred in one brand of apple cider ( $\mathrm{pH} 3.98$ ) incubated at 20 ${ }^{\circ} \mathrm{C}$. Regardless of test parameters, there was no indication that cell types differed in tolerance to the acidic environment in apple cider or orange juice. The shortest survival time was observed at $37^{\circ} \mathrm{C}$ for $9 \mathrm{~d}$ in guava, pineapple, cocktail juices, $6 \mathrm{~d}$ for orange as well as $3 \mathrm{~d}$ for apple juices respectively.

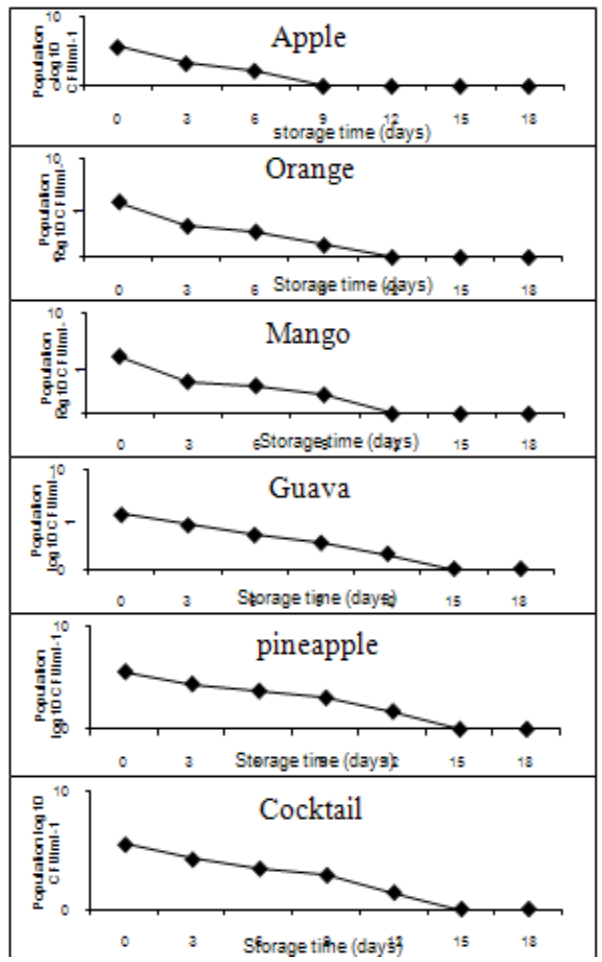

Fig. 2. Showing the changes in survival and growth of Salmonella heidelberg in fruit juices storage at $20^{\circ} \mathrm{C}$ for up to 18 days.

Other investigators study the effect of alpha- cyclodextrin-cinnamic acid inclusion complexes on populations of Escherichia coli O157:H7 and Salmonella enterica in fruit juices at two different incubation temperatures $\left(4\right.$ and $\left.26^{\circ} \mathrm{C}\right)$ and reported that, populations of $\mathrm{E}$. coli $\mathrm{O} 157: \mathrm{H} 7$ in apple cider were significantly reduced $(\mathrm{P}<$ or $=0.05)$ during the 7-day sampling period in all solutions regardless of temperature. Compared with the controls, populations were significantly reduced by the addition of 400 and 1,000 $\mathrm{mg} /$ liter inclusion complex, but reductions were not significantly different $(\mathrm{P} \geq 0.05)$ between the two treatment groups (400 and 1,000 mg/liter). Salmonella was significantly reduced in all solutions regardless of temperature. There were significant differences between the control and each inclusion complex concentration at 4 and 26 degrees Celsius. Coupled with additional processing steps, alpha-cyclodextrin-CA inclusion complexes may provide an alter native to traditional heat processes [39].

At $37{ }^{\circ} \mathrm{C}$, significant decreases in population of Salmonella heidelberg and shortest survival time was observed at $37^{\circ} \mathrm{C}$ in fruit juices under investigation (Fig. 3). The result indicated that, Salmonella heidelberg survival and grew for $9 \mathrm{~d}$ in guava, pineapple, cocktail juices, $6 \mathrm{~d}$ for orange as well as $3 \mathrm{~d}$ for apple juices respectively. The presence of 
Salmonella hiedelberg in fresh fruit juices, significant decrease was detected, where the initial mean log 10 population of Salmonella hiedelberg was 5.49 CFU ml-1 and after 3 days storage decreased to 2.66 CFU ml-1 ( $<2.83 \mathrm{CFU}$ ml-1) in apple juice, however, the Salmonella hiedelberg able to survive for up to 3 days. In orange juice Salmonella hiedelberg was survived for up to 6 days storage at $35^{\circ} \mathrm{C}$. where the initial mean $\log 10$ population was $5.22 \mathrm{CFUml}-1$ decreased to 2.18 CFUml-1 $(<3.04$ CFU ml-1). The Salmonella hiedelberg survival in mango, guava, pineapple, and cocktail at $37^{\circ} \mathrm{C}$ for up to 9 days were observed. Death was more rapid as the temperature increased and reached to zero level of Salmonella hiedelberg population. The $\mathrm{pH}$ values changes during storage of fruit juices including apple, orange, mango, guava, pineapple, and cocktail from 5.72 to 1.48 are shown in Fig.ure $(4, \mathrm{C})$.

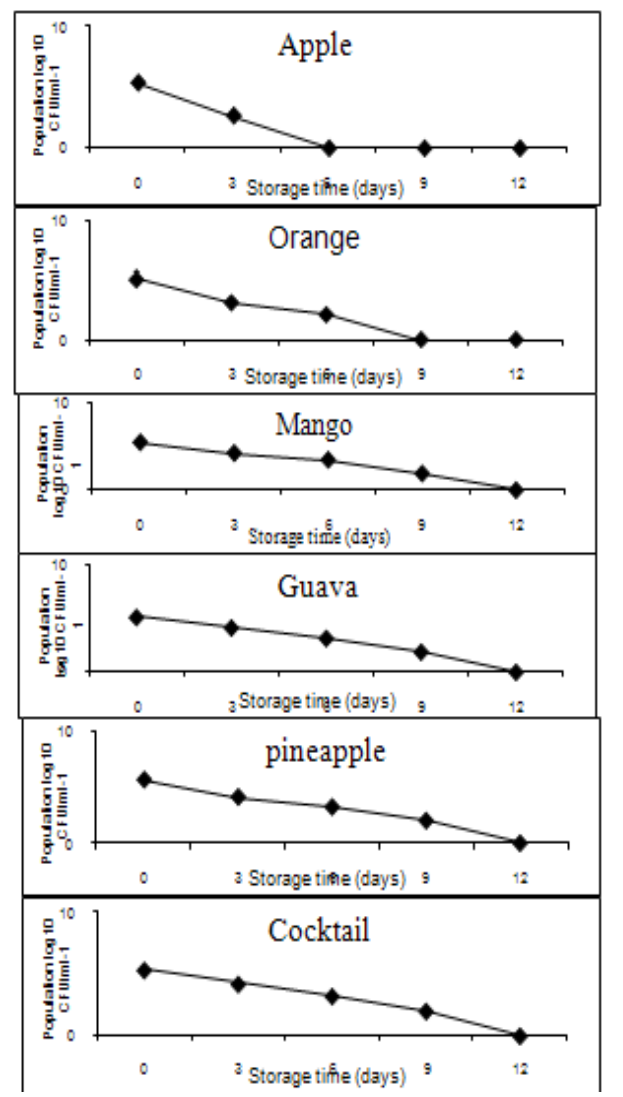

Fig. 3. Showing the changes in survival and growth of Salmonella heidelberg in fruit juices storage at $37{ }^{\circ} \mathrm{C}$ for up to 12 days.

Several investigators examined the behavior of pathogenic bacteria in fruit juices, unpasteurized fruit and vegetable juices [40], fruit juices [41], orange juice [42], fresh fruit juices and melon and watermelon juices [43, 44], orange and apple juices [45], strawberry juice [46], and orange juice [32], Moreover, the influence of preadaptation strains to an acidic environment by subculturing individual strains of a 15-strain cocktail at $\mathrm{pH} 5.5$ prior to mixing and inoculation into high salt $(13.5 \% \mathrm{w} / \mathrm{v})$, reduced $\mathrm{pH}(4.9)$, TSB stored at $20{ }^{\circ} \mathrm{C}$. Under these storage conditions, there is no advantage conferred to cells that were acid-adapted [47].
In addition to that, acid-adapted cells retain higher viability than unadapted cells in only two of nine foods tested [27].

On the other hand, there are many methods used to safe the fruit juices, [48], for instance, Osmosonication represents a potential processing alternative for producing safe and high-quality concentrated fruit juice without applying thermal treatments. Findings reported in this article can also be applied by industries when concentrating juices by classical means at relatively low temperature. It provides industries with a mathematical model specific for blackberry juice, from which different combinations of sonication time and storage time of concentrate can be chosen to achieve safety and quality goals. Moreover, the effect of continuous ohmic heating to inactivate Escherichia coli O157:H7, Salmonella Typhimurium and Listeria monocytogenes in orange juice and tomato juice and reported that, continuous ohmic heating can be effective in killing foodborne pathogens on orange juice and tomato juice with lower degradation of quality than conventional heating [49].

\section{Conclusion}

Survival in fruit juices depended upon their $\mathrm{pH}$, the type of strain, the type of juices and the incubation temperature. Salmonella heidelberg Survived for up to $18 \mathrm{~d}$ in mango, guava, pineapple and cocktail juices, orange juice for up to $15 \mathrm{~d}$ and apple juice for up to $12 \mathrm{~d}$ stored at $10^{\circ} \mathrm{C}$. At $20^{\circ} \mathrm{C}$, Salmonella heidelberg was survived for up to $12 \mathrm{~d}$ in guava, pineapple and cocktail juices, $9 \mathrm{~d}$ for mango juice, orange juice for up to $9 \mathrm{~d}$ and apple juice for up to $6 \mathrm{~d}$. The shortest survival time was observed at $37^{\circ} \mathrm{C}$ for $9 \mathrm{~d}$ in mango, guava, pineapple, cocktail juices, $6 \mathrm{~d}$ for orange as well as $3 \mathrm{~d}$ for apple juices respectively. These findings indicated that, as temperatures of acidify fresh fruit juices (apple, orange, mango, guava, pineapple and cocktail juices, respectively) increases as Salmonella heidelberg population decrease.

\section{References}

[1] Mead PS, Slutsker L, Dietz V, et al. Food-related illness and death in the United States. Emerg In-fect Dis 1999;5:607-625.

[2] Voetsch AC, Van Gilder TJ, Angulo FJ, et al. (2004). FoodNet estimate of the burden of illness caused by nontyphoidal Salmonella infections in the United States. Clin. Infect. Dis., 38 Suppl 3: S127-S134.

[3] Williams, J. E. (1965). Paratyphoid and arizona infections, p. 260-328. In H. E. Biester and L. H. Schwarte [ed.], Diseases of poultry, 5 th ed. The Iowa State Univ. Press, Ames.

[4] CDC. 2007. National Antimicrobial Resistance Monitoring System for Enteric Bacteria (NARMS): human isolates final report, 2003. CDC, Atlanta, GA.

[5] CDC. 2007. National Antimicrobial Resistance Monitoring System for Enteric Bacteria (NARMS): human isolates final report, 2004. CDC, Atlanta, GA.

[6] FDA. 2006. National Antimicrobial Resistance Monitoring 
System-Enteric Bacteria (NARMS): 2003 Executive Report. FDA, Bethesda, MD.

[7] Zhao, S., P. F. McDermott, S. Friedman, J. Abbott, S. Ayers, A. Glenn, E. Hall-Robinson, S. K. Hubert, H. Harbottle, R. D. Walker, T. M. Chiller, and D. G. White (2006). Antimicrobial resistance and genetic relatedness among Salmonella from retail foods of animal origin: NARMS retail meat surveillance. Foodborne Pathog. Dis. 3:106-117.

[8] Chittick, P., A. Sulka, R. V. Tauxe, and A. M. Fry. (2006). A summary of national reports of food-borne outbreaks of Salmonella heidelberg infections in the United States: clues for disease prevention. J. Food Prot. 69:1150-1153.

[9] Currie, A., L. MacDougall, J. Aramini, C. Gaulin, R. Ahmed, and S. Isaacs. (2005). Frozen chicken nuggets and strips and eggs are leading risk factors for Salmonella heidelberg infections in Cana-da. Epidemiol. Infect. 133:809-816.

[10] PHAC (Public Health Agency of Canada) (2007). Salmonella heidelberg ceftiofur related resistance in human and retail chicken isolates. Public Health Agency of Canada, Guelph, Ontario, Canada. http://www.phac-aspc.gc.ca/cipars-picra/heidelberg/pdf/heid elberg_e.pdf.

[11] Barnass, S., M. O’Mahony, P. N. Sockett, J. Garner, J. Franklin, and S. Tabaqchali. (1989). The tangible cost implications of a hospital outbreak of multiply-resistant Salmonella. Epidemiol. In-fect. 103:227-234.

[12] CDC, (1986). Salmonella heidelberg outbreak at a convention-New Mexico. MMWR Morb. Mortal. Wkly. Rep. 35:91.

[13] Choi, M., T. T. Yoshikawa, J. Bridge, A. Schlaifer, D. Osterweil, D. Reid, and D. C. Norman. (1990). Salmonella outbreak in a nursing home. J. Am. Geriatr. Soc. 38:531-534.

[14] Layton, M. C., S. G. Calliste, T. M. Gomez, C. Patton, and S. Brooks (1997). A mixed foodborne outbreak with Salmonella heidelberg and Campylobacter jejuni in a nursing home. Infect. Control Hosp. Epidemiol. 18:115-121.

[15] Lyons, R. W., C. L. Samples, H. N. DeSilva, K. A. Ross, E. M. Julian, and P. J. Checko. (1980). An epidemic of resistant Salmonella in a nursery. Animal-tohuman spread. JAMA 243:546-547.

[16] Feng, P. (1992). Commercial assay systems for the detecting food borne Salmonella: a review. J. Food Prot. 55:927-934.

[17] Tietjen, M. and D. Y. C. Fung, (1995). Salmonellae and food safety. Crit. Rev. Microbiol. 21(1):53-83.

[18] Beuchat, L. R., (1995). Pathogenic microorganisms associated with fresh produce. J. Food Prot. 59:204-216.

[19] D’Aoust, J., (1997). Salmonella species, p. 135-137. In M. P. Doyle, L. R. Beuchat, and T. J. Montville (ed.), Food microbiology: fundamentals and frontiers. American Society for Microbiol-ogy, Washington, D.C.

[20] Doyle, M. P., T. Zhao, J. Meng, and S. Zhao, (1997). E. coli O157:H7, p. 175-178. In M. P. doyle, L. R. Beuchat and T. J. Montville (ed.), Food Microbiology: fundamentals and frontiers. Ameri-can Society for Microbiology, Washington, D.C.

[21] Cohen, J. I., J. A. Bartlett, and G. Ralph Corey, (1987). Extra-intestinal manifestations of Salmonella infections. Medi- cine 66:349-387

[22] Goldberg MB, Rubin RH. (1988). The spectrum of Salmonella infection. Infect Dis Clin North Am. 1988 Sep;2(3):571-598.

[23] Rodriguez M., De Diego I., and Carmen M. M. (1998). Extraintestinal Salmonellosis in a General Hospital (1991 to 1996): Relationships between Salmonella Genomic Groups and Clinical Presentations. J. Clin. Microbiol., 36(11): 3291-3296.

[24] Buchanan, R. L. and Edelson, S. G. (1996). Culturing enterohaemorrhagic $E$. coli in the presence and absence of glucose as a simple means of evaluating the acid tolerance of stationary phase cells. Appl. Environm. Microbiol., 62:4009-4013.

[25] McCarthy, J., Holbrook R. and Stephens, P. J. (1998). An improved direct plate method for the enumeration of stressed E. coli O157:H7 from food. J. Food Prot., 61:1093-1097.

[26] Jordan, K. N., Hall S. and MacClure P. J. (1999). Osmotic stress on dilution of acid injured E. coli O157:H7. Lett. Appl. Microbiol.. 28:389-393.

[27] Deng, Y., Ryu J. H. and Beuchat, L. R. (1999). Tolerance of acid-adapted and non-adapted E. coli O157:H7 cells to reduced $\mathrm{pH}$ as affected by type of acidulant. J. Appl. Microbiol., 86:203-210.

[28] Gomutputra , C. and Fabian, F. W. (1953). Acids and chloramphenicol as sanitizing agents for meat contaminated with food-poisoning organisms. Journal of Milk and Food Technology 16, 220-227.

[29] El-Safey, E. M. and Ammar M. S., (2002c). Survival and growth of $E$. coli $\mathrm{O} 157: \mathrm{H} 7$ population in acidulous pickled vegetables. 18th international ICFMH Symposium Food Micro 2002, Lille-hammer, Norway 18-23 August 2002. pp. 217.

[30] Vantarakis A, Affifi M, Kokkinos P, Tsibouxi M, Papapetropoulou M. (2011). Occurrence of microorganisms of public health and spoilage significance in fruit juices sold in retail markets in Greece. Anaerobe. 17(6):288-291.

[31] HE and Ingham SC (1999). Combinations of Intervention Treatments Resulting in 5-Log10-Unit Reductions in Numbers of Escherichia coli $\mathrm{O} 157: \mathrm{H} 7$ and Salmonella typhimurium DT104 Organ-isms in Apple Cider. Appl. Environ. Microb., 65( 5): 1924-1929.

[32] Noël H, Hofhuis A, De Jonge R, Heuvelink AE, De Jong A, Heck ME, De Jager C, van Pelt W. (2010). Consumption of fresh fruit juice: how a healthy food practice caused a national outbreak of Salmonella Panama gastroenteritis. Foodborne Pathog Dis. 2010 Apr;7(4):375-381.

[33] Bagamboula CF, Uyttendaele M, Debevere J. (2002). Acid tolerance of Shigella sonnei and Shigella flexneri. J. Appl. Microbiol. 93(3):479-486.

[34] El-Safey, E. M., (2001). Search for E. coli O157:H7 in Egyptian foods and dairy products. PhD. Sci. A thesis, Bot. and Microbiol. Dept., Fac. Sci., Al-Azhar Univ., Cairo, Egypt.

[35] Anderson, M. E., Huff H. E., Naumann H. D., Damare J. M., Partt M., Johnson R. and Marshall R. T., (1987a). Evaluation of an automated beef carcass washing and santizing system 
under production conditions. J. Food Prot. 50 : 562-566.

[36] Anderson, W. H., Wildon C. R. and Poelma P. L., (1987b). Glucuronidase assay in a rapid MPN determination for $E$. coli from selcted foods. J. Assoc. Off. Anol. Chem. $70: 31-34$.

[37] Dickson J. S. and Anderson, M. E. (1992). Microbiological decontamination of food animal car-casses by washing and sanitizing systems: a review. J. food prot. 55:133-140.

[38] Nicolò MS, Gioffrè A, Carnazza S, Platania G, Silvestro ID, Guglielmino SP.(2011). Viable but nonculturable state of foodborne pathogens in grapefruit juice: a study of laboratory. Foodborne Pathog. Dis., 8(1):11-17.

[39] Truong VT, Boyer RR, McKinney JM, O'Keefe SF, Williams RC. (2010). Effect of alpha-cyclodextrin-cinnamic acid inclusion complexes on populations of Escherichia coli O157:H7 and Salmonella enterica in fruit juices. J Food Prot. 73(1):92-96.

[40] Little CL, Mitchell RT; Food Standards Agency; Local Authorities Coordinators of Regulatory Services; Health Protection Agency (2004). Microbiological quality of pre-cut fruit, sprouted seeds, and unpasteurised fruit and vegetable juices from retail and production premises in the UK, and the application of HAACP. Commun. Dis. Public Health., 7(3):184-190.

[41] Raybaudi-Massilia RM, Mosqueda-Melgar J, Martín-Belloso O (2006). Antimicrobial activity of essential oils on Salmonella enteritidis, Escherichia coli, and Listeria innocua in fruit juices. J. Food Prot., 69(7):1579-1586.

[42] Whitney BM, Williams RC, Eifert J, Marcy J. (2007). High-pressure resistance variation of Esche-richia coli O157:H7 strains and Salmonella serovars in tryptic soy broth, distilled water, and fruit juice. J. Food Prot. 70(9):2078-2083.

[43] Mosqueda-Melgar J, Elez-Martínez P, Raybaudi-Massilia RM, Martín-Belloso O (2008a). Effects of pulsed electric fields on pathogenic microorganisms of major concern in fluid foods: a review. Crit. Rev. Food Sci. Nutr., 48(8):747-59.

[44] Mosqueda-Melgar J, Raybaudi-Massilia RM, Martín-Belloso O (2008b). Combination of high-intensity pulsed electric fields with natural antimicrobials to inactivate pathogenic microorgan-isms and extend the shelf-life of melon and watermelon juices. Food Microbiol. 25(3):479-491.

[45] Alvarez-Ordóñez A, Fernández A, Bernardo A, López M (2009). A comparative study of thermal and acid inactivation kinetics in fruit juices of Salmonella enterica serovar Typhimurium and Salmonella enterica serovar Senftenberg grown at acidic conditions. Foodborne Pathog Dis., 6(9):1147-1155.

[46] Duan J, Zhao Y. (2009). Antimicrobial efficiency of essential oil and freeze-thaw treatments against Escherichia coli O157:H7 and Salmonella enterica Ser. Enteritidis in strawberry juice. J. Food Sci., 74(3):M131-137.

[47] McClure, P. J. and Hall, S. (2000). Survival of E. coli O157:H7 in foods. J. Appli. Microbiol. Sympo. Suppl., $88: 61 \mathrm{~S}-70 \mathrm{~S}$.

[48] Wong E, Vaillant F, Pérez A. (2010). Osmosonication of blackberry juice: impact on selected pathogens, spoilage microorganisms, and main quality parameters. J Food Sci., 75(7):M468-474

[49] Lee SY, Sagong HG, Ryu S, Kang DH. (2012). Effect of continuous ohmic heating to inactivate Escherichia coli O157:H7, Salmonella typhimurium and Listeria monocytogenes in orange juice and tomato juice. J Appl Microbiol. 2012 Apr;112(4):723-731.

[50] USDA. National Antimicrobial Resistance Monitoring System for Enteric Bacteria (NARMS). USDA, Washington, DC http://www.ars.usda.gov/Main/docs.htm?docid_6750\&page_4. 